\title{
Impact Evaluation of a Project on Alternative Energy "Biogas Plants" in Sindh, Pakistan
}

\author{
Sayed Sada Husssain Shah \\ Department of Sociology, University of Sindh Jamshoro, Hyderabad 71000, Pakistan
}

Received: March 29, 2016 / Accepted: April 06, 2016 / Published: July 31, 2016.

\begin{abstract}
The core purpose of impact study was to collect best practices learnings of project through the reflection of communities or end users. During analysis and interpretation of data, some touch of context is also given to clear the picture of weakness and strengths of project theory in terms of context. The main objective of project under study was to provide alternative energy to the communities living inside forest to reduce wood cutting for domestic purpose. Though there were many short term surveys were conducted during project, such as, average wood consumption at household level, community motivation survey. Instead to all MRDS (Mehran Research \& Development Society) felt need to conduct a detailed impact evaluation to see overall impact of project implementation and review on the life of end users or communities. After three years of project exit, MRDS conducted a qualitative impact study of project in the end of 2014. There were three key questions to explore during study: What was the overall impact of project on end users? What the best practices of project and why? What are project learnings and how?
\end{abstract}

Key words: Bio-gas plant, preservation of forest wood, worldwide fund for nature.

\section{Introduction to Project or Theory of Operation}

The project was implemented only in two villages, eight household biogas plants were constructed two villages (Umer Palari and Natho Kolhi).

Project "provision of alternative energy" was funded by WWF-Pakistan "Indus forever programme" through partnership fund. The category of fund comes under small grants programme which is managed by WWF-Pakistan head office "Lahore". The objectives of project were community sensitization regarding importance and preservation of forest and provision of renewable alternative energy "biogas plants" to reduce use of wood burning at house hold level as fuel.

According to the indicators of achievement on house hold of size 7-9 family members use 900-1,200 kg of wood per month for cooking purpose, so with construction of single biogas plant in a house we may

Corresponding author: Sayed Sada Husssain Shah, Ph.D. scholar, research fields: environment, gender, mother and child health, food security and nutrition. save $900-1,200 \mathrm{~kg}$ of wood per month.

Overall objective of project is to construct eight biogas plants, six at Miyani forest and two at Khaibrani forest Matiyari, so at the completion of project we may ultimately save 7,200-9,600 kg of wood per month.

Total eight biogas plants were constructed in project six in Miyani forest, which is near to Hyderabad city, the second big city of Sindh. Two biogas plants were constructed in Khaibrani forest which is at the distance of 45 kilo-meters from Hyderabad city.

Community was not interested and motivated to use biogas plants during first quarter of project and three constructed plants could not be functional. On the basis of these learning the short motivation and need measurement survey was conducted by project staff. Survey proved that kitchen management is the responsibility of women, so project mobilization must be focused on women. In the next quarter home to home mobilization and awareness was conducted by female social mobilizers and project started running successfully. 
During first quarter, three biogas plants were constructed and two interactive theatres were performed for community awareness and sensitization, during 2nd quarter, three biogas plants were constructed at Colhi community at Miyani forest and formed a community volunteer group at Khaibrani forest Matiyari in third and final quarter of implementation two biogas plants were constructed at Khaibrani forest. For community motivation experiment of gas lamp was conducted which went very well and sought more attention of end users, "This experiment was first conducted in India by farmers".

To increase more input from users side MRDS conducted the activity of "best end user award" that was given to Mr. Haroon Palari which supported project team during experiment on gas lamp. In the result of that activity Mr. Hameed Palari and his cousin Hameed Palari supported project team in conducting the experiment on results of nitrogenous waste products of biogas plant and chemical fertilizers in their field of onions. In Sindh this experiment was first conducted by M. H. Panhwar at Sindh Agriculture University Tando Jam.

During 3rd quarter of project two biogas plants were constructed in Khaibrani forest which both are size of eight cubic meters. Previously constructed biogas plants were three cubic meters in size, during the six months of project, it was found that size of biogas plants should be more than three cubic meters because cow dung in Sindh contains more ratio of $\mathrm{H}_{2} \mathrm{O}$ and Nitrogen as compare to Hydro Carbon. It was necessary to construct eight cubic meters plant to fulfil the fuel for cooking needs of a family of 6-8 members.

Major activities conducted since first quarter to final were, construction of six biogas plants at Miyani forest and two at Khabirani forest, performance of two interactive theatres for community awareness, formation four community volunteer groups (two male and two female) two at Miyani forest and two at Khaibrani forest. However, award of best end user of biogas plant and gas lamp experiment were also conducted for community motivation. After first quarter of project, team felt need of women leadership and formed women volunteer groups, this excrement went very well. "Women are proved more cooperative, nature loving, innovative and sparking as compare to the men of communities" said by social mobilizers.

In the first quarter project was not going on track to succeed. Later on implementation strategy was changed. Mobilization was done with women who were the actual custodian of kitchen. For motivation of community new experiments and best user awards ceremonies were conducted. At the end of project MRDS saved 68,400 to $115,200 \mathrm{~kg}$ of wood at both of the forests.

\section{Introduction to Project Context}

The project was implemented in three villages inside two Riverine forests. Miyani forest is located at the side of national highway and people have access to urban area. Inside the forest there were only on shop for basic facilities, just at next side of national highway apposite to the Miyani forest there was a tea point. People in Miyani forest have access to electricity and mobile phone service. Politically of the people living in Miyani forest were the voters of Pakistan Peoples' Party, which is considered liberal Democratic Party of country. One village was targeted under the project that was consist on two clusters. In one cluster $100 \%$ population was Muslim and in other cluster $100 \%$ Hindu population but both vote for same political party. The distance between both of the clusters was just 100 meters and people have access to each other, both of the communities were very social with each other. $80 \%$ of the population of both clusters depends on agriculture, $15 \%$ was agriculture and daily wage laborers, $3 \%$ private employment and $2 \%$ government employment, in forest department. A combine primary schools for girls and boys was available in one cluster with Muslim population were children from both of the clusters could access. Though there was no separate school for Hindu community in their own cluster, so 
the attendance of Hindus students was very low. Most of the population were poor or very poor only any landlord or upper class household found in area, the land owners live in Hyderabad city that is 9 kilo-meters away from Miyani forest. For transport access communities have option to use public transport running on national highway, few of the households also own the motor bikes. The wood cutting practice was done by people to get the fuel for cooking, or to use it in building houses and also to sell it in market. Majority of wood amount was cut for fueling, second majority to use it in building the roofs of houses. The people depending on agriculture also own big livestock including cows and buffaloes, whereas other than agriculture dependents usually own small livestock such as, goats and sheep.

The dynamics of Khaibrani forest were also the same but there were minor changes in socio-economic conditions of Khaibrani forest. It is away from national high way road access is also very poor, people mostly use motor bike for transport which is costly as compare to public transport. There was only one village in forest and all of the households were Hindus, electricity, school and shops were not available in village. People used to walk 20 kilo-meters to buy goods for basic needs from small town. $90 \%$ of the population is agriculture and livestock dependents where as $10 \%$ was daily wage laborers. Due to lack of road access, they cut forest wood only for cooking fuel and using it to build the roofs of houses. Even for building houses, people of Khaibrani forest do not use very heavy wood because they build very simple houses like huts with mud walls and thatched roof.

Considering the literacy rate and overall exposure of communities with modern technology, choosing biogas plants to produce methane gas at household level was not an easily feasible strategy. Due to low conductive context for using modern technologies MRDS adopted different approaches to motivate, aware and educate people. Teaching people about the use of biogas plants, reduction in wood cutting, environmental protection and use of solid waste in agriculture was not an easy task. The approach of interactive theaters helps MRDS a lot to educate people about such complex ideas and scientific phenomenon that are beyond the understanding of low educated people.

\section{Scope of Study}

Impact study was conducted on all the eight households of both villages, those were provided biogas plants under project. Household those constructed biogas plants by their selves were not the part of study. Data were collected from adult (above 18 years) male and female members of each household. Two members of each household ( 8 households) were interviewed in detail. For the secondary evidences, projects' reports were reviewed. In depth interview technique was used as tool of data collection. All the beneficiary households were selected using non-probability purposive (criterion purposive) sampling. Detailed information on project barriers and boosters were collected from field.

The ultimate scope or use of study can be, to design any new development projects on use of alternative energies and preservation of forests in low educated communities of developing countries. The study supported a lot in exploring few new approaches for triggering change in community behavior.

The study shows overall achievement of project including institutional support to MRDS, for example, MRDS got network membership with REEP (Renewable Energy \& Energy Efficiency Partnership).

\section{Objectives of Study}

- To know the contribution of biogas plants in saving forests' wood being used as domestic fuel at Miyani and Khabirani forests at the end of project;

- To measure the barriers and boosters of context towards project interventions during period of project implementation;

- To measure the role of gender in project success during project life in selected area. 


\subsection{Research Questions}

Reflecting the objectives of study, the following key research questions were proposed. Each research question was placed as section, in questionnaire, five to ten questions were developed under each section.

- Amount of wood $(\mathrm{kg})$ saved by single biogas plant around the year;

- Difficulties faced by people in using biogas plants and mitigations;

- Impact of changing mobilization approaches, on use of biogas plants;

- Role of women in overall success of project.

\section{Research Methodology}

\subsection{Type of Study}

Proposed study is operational research, operational research is applied when you test or measure any operation or project. Proposed study wants to measure the impact of operation or project in a given context, like rural communities living inside forest area of Sindh.

\subsection{Approach of Study}

That impact evaluation was conducted with realistic or contextual approach. Approach of realistic evaluation was given by American sociologists Pawson and Tilly in 1997. In this approach we measure the results of any project approach against the context or situation in which it was being implemented. If a project has good results in context of South Sudan, Africa, it is not guaranteed that same project theory will have good results at similar level in context Pakistan. Real evaluation studies the results of project along with the context of project and recommend replication of project in similar context with or without any changes in project theory.

\subsection{Research Method}

Mixed method of approaches are applied in study, both qualitative and quantitative. In depth interviews technique was applied to collect data from respondents. Semi structured interview guide was developed having both, open ended and closed ended questions.

\subsection{Methods and Tools of Data Collection}

Desktop review of secondary data was conducted at the office of MRDS. Project proposal, project reports, baseline study and other short surveys were reviewed in detail. After the study of secondary data, primary data were collected from fields. Primary data were collected from male and female beneficiaries or users of biogas plants, using in-depth interview technique.

In-depth interviews were conducted with male and female from each user house. For conducting in-depth interviews semi-structured interview schedule method.

\subsection{Study Targets}

Study was conducted in two villages (one at Miyani forest and one at Khabirani forest), data were collected from one adult male and one adult female of each user household. There were total 8 biogas plants constructed in 8 households, all the households were interviewed.

\subsection{Method of Sampling}

The proposed study was operational research, for operational studies, non-probability purposive sampling is recommended, subtype of purposive sampling the criterion purposive was used. Non-probability purposive sampling is used when the targets of study are already known. All the targets were selected on the basis of some criteria; respondent must be above 18 years, must be the user of biogas plant, must have involved in maintenance and use of biogas plants and have attend awareness gatherings and interactive theaters during project. When we select respondents on a fixed criteria purposively, it is called criterion purposive sampling method. Ted Plays (Ph.D.), professor, School of Criminology \& Associate Member, Department of First Nations Studies, Simon Fraser University, Burnaby BC Canada, was the man who has worked on purposive sampling in detail. 


\section{Findings and Discussion}

\subsection{Village Demography}

Two villages were studied, where the project was being implemented. Village Natho Kolhi from Khabirani forest district Matiyari, and village Umer Palari from Miyani forest district Hyderabad, Sindh. Kolhi is a minority community in Pakistan, they belong to Hindu religion and are considered as schedule caste. Kolhi community in Sindh is well known farming community and can be easily found in agriculture areas of south Sindh. These communities have historic and cultural links with desert of Sindh (nowadays district Tharparkar), but they can be traced back to the age of Indus Civilization. In recent times, due to poverty and lack of employment opportunities in district Tharparkar these communities migrated from Tharpakar (still migrating) and worked in agriculture fields in districts located adjacent to district Tharparkar.

Total $75 \%$ of our project beneficiaries were from Kolhi community, two households from Village Natho Kolhi and four households from village Umer Palari. The reasons why we took them as our beneficiaries are that they keep livestock, they belong with poor class and they are very hard worker. As shown in Fig. 1, there were 95 households in village Natho Kolhi out of which only 2 households were selected, following the beneficiary selection criteria. As shown in Fig. 2, there were 111 households in village Umer Palari out of

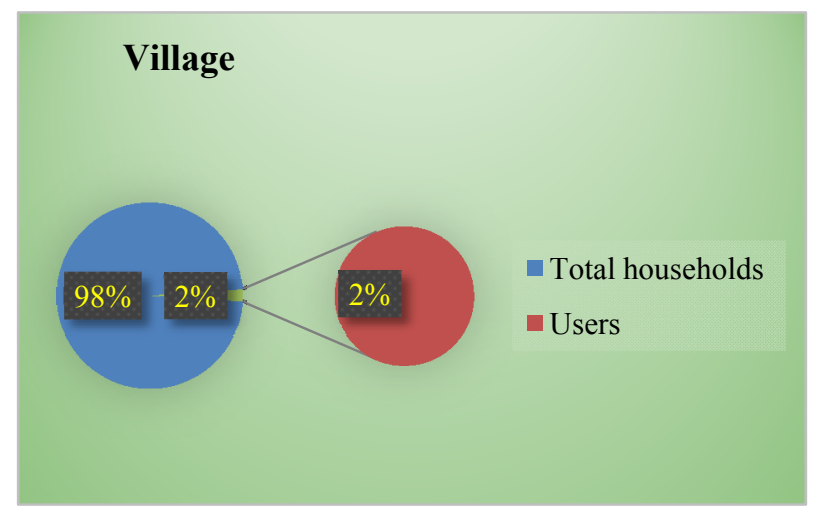

Fig. 1 Village demography. which 6 households were selected. Village Umer Palari has majority of Muslim community, there were 15 households of Kolhi community out of which 4 households were selected. Palari is Muslim community originally belongs to hilly areas (Kheer Thar hills) of district Jamshoro. This community is also working very hard, mostly associated with business and government jobs. The reason why only 2 households of Palari community out of 80 households were selected is that majority of them were government employees at forests. The average household population of both of villages is 10 members per household.

\subsection{Livestock Population and Availability of Dung/Green Manure}

Availability of livestock and green manure was the essential criterion of project, because a 3 cubic meters' biogas plants needs $10 \mathrm{~kg}$ of green manure per day to produce reasonable amount of methane gas. As shown in table there were 8 buffalos in two households of village Natho Kolhi (average 4 per house) and 10 cows (average 5 per household). In village Umer Palari, the number of buffalos was relatively high as compared to cows. Livestock population per household was enough to produce reasonable green manure every day. There were also many other types of livestock in village but these were not taken into consideration, because in context of this project livestock was taken as the source of green manure instead of as the source of income. As per recommendation of technical experts only the dung

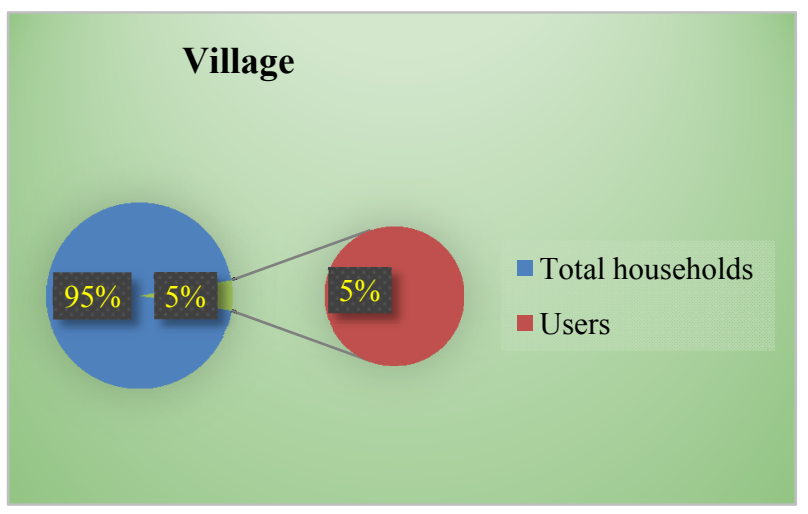

Fig. 2 Village demography. 
Table 1 Availabilty of green manure for biogas plans.

\begin{tabular}{lllll}
\hline & $\begin{array}{l}\text { Total dung producing } \\
\text { livestock }\end{array}$ & Number & $\begin{array}{l}\text { Livestock with user } \\
\text { households }\end{array}$ & Number \\
\hline \multirow{2}{*}{ Village: NathoKolhi } & Buffalos & 339 & Buffalos & 8 \\
& Cows & 103 & Cows & 10 \\
\multirow{2}{*}{ Village: UmerPalari } & Buffalos & 4,003 & Buffalos & 18 \\
& Cows & 116 & Cows & 12 \\
\hline
\end{tabular}

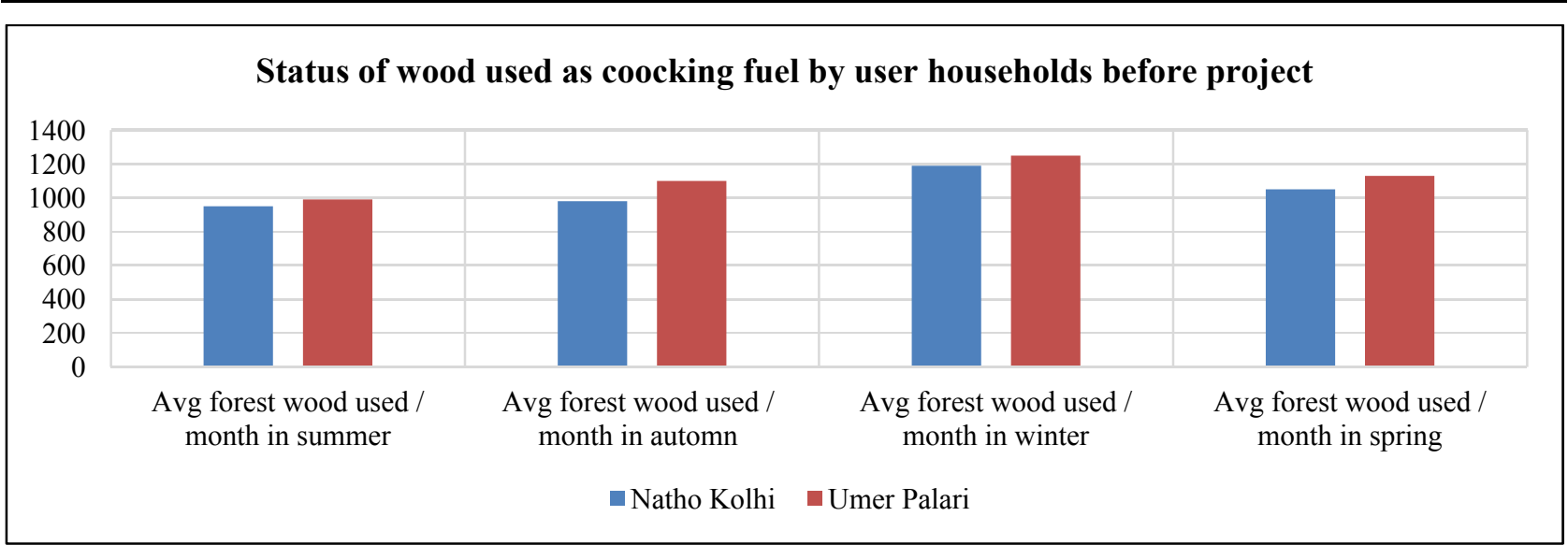

Fig. 3 Use of wood at household and village level.

of cows and buffalos was used as a green manure for biogas plants. Table 1 shows that each household/user of biogas plant in village Natho Kolhi have 8 buffalos or 10 cows and each selected user in village Umer Palari have 18 buffalos or 12 cows. This number of animals is quite accurate to produce minimum green manure per day to feed in biogas plant constructed at household level.

\subsection{Fuel (Wood) Used by Villages}

As shown in Fig. 3, 900 to 1,200 kg of wood was being used by a household in a month as fuel for cooking purpose. After the installation of 8 biogas plants at 8 households, MRDS became able to save 7,200 to $9,600 \mathrm{~kg}$ of wood per month. During the year of project MRDS has preserved or saved 68,400 to $115,200 \mathrm{~kg}$ of wood in both of forests with equal proportion. Each biogas plant has 8 years' guaranty, it can be increased if used safely. Let us take the minimum example, we have conducted this research between four to five years and bio-gas plants are still functional and during these five years project has saved 342,000 to $576,000 \mathrm{~kg}$ of wood. On average, single household biogas plant of 3 cubic meters' can save

\section{$14,400 \mathrm{~kg}$ of wood in a year.}

If the communities used biogas plants continuously for such a long time, they will be habitual and as it is seen through community behavior they will be repairing and maintaining their biogas plants by their own, and finally the preservation of thousands of trees will be made sure. Many of the new households are also thinking to construct biogas plants by their own, they belong to middle class and they can afford the expenses, MRDS is also ready to provide technical guidance without any cost. This change of behavior is happening due to the mobilization of women of community, women are good motivators for other women and they are very generous to share their experiences to other women that is the why passion of biogas plants is increasing in area, even four years are passed to project exit.

\subsection{Impacts of Innovations}

As discussed above how much wood was being saved through construction of 8 biogas plants in both villages. Let's explore the mechanism how project has achieved such success during the year of implementation. It is really wonder to know that just 
after three months of project, approach of project execution was totally changed and just after one more month (forth month) significant change was observed. Both of the changes played the key role in project success and these are the major learnings for every organization that is planning to work on alternative energies in context of Sindh, Pakistan. Let's discuss these learnings and innovations one by one.

\subsubsection{Involvement of Women}

At initial stage the project was completely designed for male community members. Because wood cutting and arrangement is their responsibility, so it was felt necessary to sensitize them on use of biogas plants as an alternative energy source so that wood cutting may be reduced. During first quarter of project male members of community were trained in using biogas plants and sensitized about importance trees through interactive theaters.

Just after two months, project team received many complaints from community concerned with the usage of biogas plants. All the complaints were received through female social organizer of project. For project team it was wonder to know that all the trained male community members just oriented to their female to use the biogas plant and they have not done anything by themselves. Information passed to women was not enough to use the biogas plants properly because using a biogas plant is completely scientific, from the stage of filling green manure up to the preparing nozzle of stove. Suddenly the project team decided to build capacity of the women of community.

Women learned very quickly about the use of biogas plants, they were more punctual about the maintenance of biogas plants.

When impact evaluation team asked from them why are you more punctual to use the biogas plants? They replied, these are smoke free and these can save our trees. In Pakistan cooking is the job of women so they could realize the importance of biogas plants. After further probing, why do you want to save your trees? The reasons were not any scientific but the artistic, women believe that trees are beautiful, they provide shade in summer days and many beautiful birds are living in trees. Women of village really do not need big reasons to do big things, they see their life in small things and they are more nature friendly.

On the behalf of this learning, we will recommend any organization working on environment, must take women as a lead role in their project. Women are more loving to environment and nature as compared to men, especially in context of rural areas of Sindh/Pakistan (see Fig. 4).

\subsubsection{Experiment of Gas Mantel}

People like new things or innovations that are not explained to them during project introduction. When you implement any scientific project people feel they would be able to see any miracle of science. On the behalf of learning from this project, we recommend to plan some innovations for your project, keep these hidden from community and use these as a booster when you feel community is getting lazy. In development sector, community activeness and full cooperation are necessary and that is always difficult. Because, community has a lot of other things to do for their livelihood and social life. It is really a big question that why people pay full attention to your project all the time?

Being research organization, MRDS conducted a survey on what next people want from biogas plants. After conducting meetings with community around

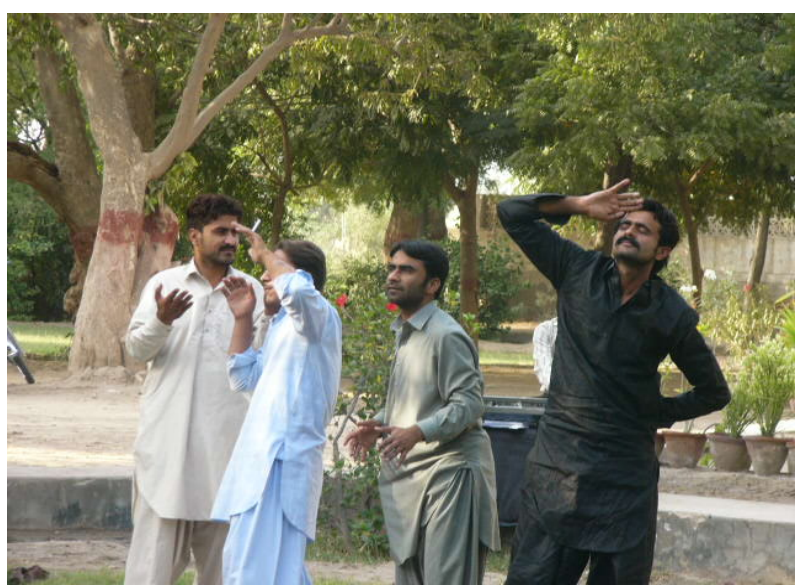

Fig. 4 Men in context of rural areas of Sindh/Pakistan. 


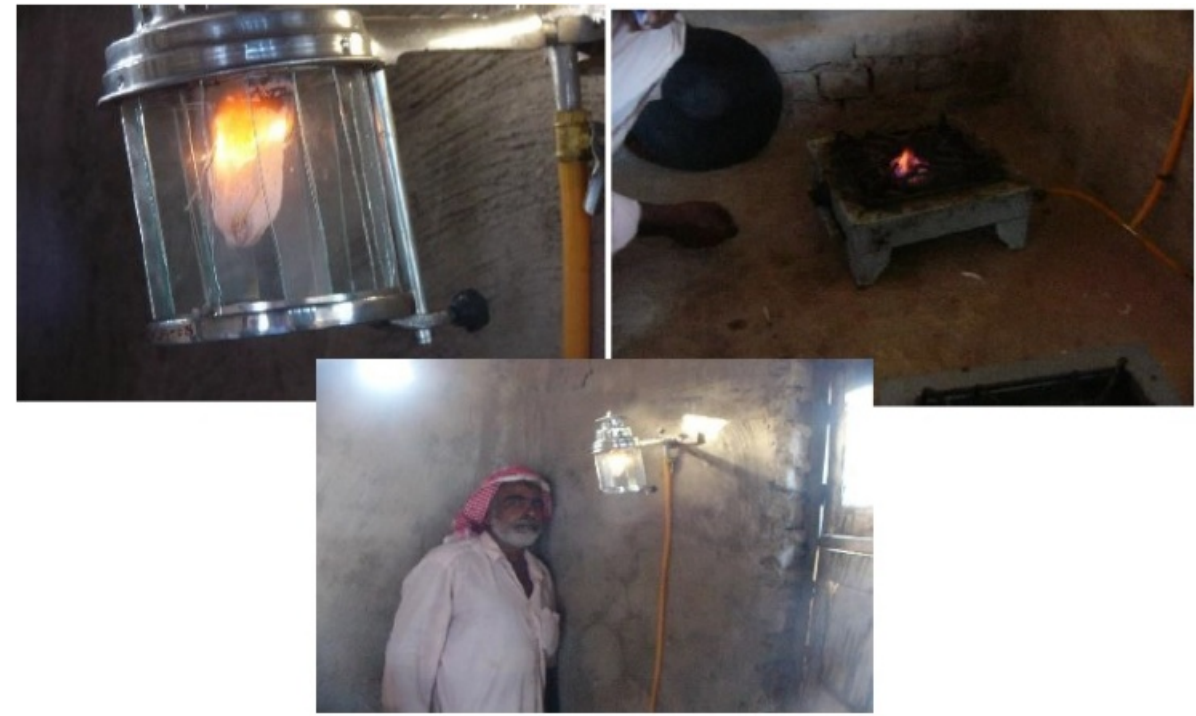

These pictures were taken by field team of Alternative Energy project_funded by WWF_2009 T0 2010

Fig. 5 Experiment of gas lap with a selected household in village Umer Palari.

topic, survey team came to know people feel difficulty of lighting at their cooking place during preparation of dinner. Suddenly the project implementation team has an idea to conduct experiment of gas mantel/lamp. Fig. 5 shows the gas lamp is producing light and stove is burning on same time. The man shown under the lamp is user of biogas plant and he is also a local electrician, he helped project team to execute the experiment.

A motivated household was selected in village Umer Palari for this experiment, the household head (Haroon Palari) was also talented in electric works and he was very happy to listen about that experiment. This experiment was not the part of project, never even thought before, four months were completed with implementation. This experiment was first tried in India in similar type of project.

That experiment became the booster for using of biogas plant, all the other users started using gas mantel/lamp. It is really a big indicator of community interest when they share their costs in your project by their will. After conducting that experiment with household, rest of households were said to replicate that by their own expenses. After four years when this evaluation was being conducted, evaluation team found that all of the households still have functional gas mantels/lamps.
Note: For any person or organization who wish to repeat that experiment, application is given as annex 1 at the end of the study report.

\section{Conclusions}

Impact study of project "Provision of Alternative Energy to reduce wood cutting at Miyani and Khaibirani forests, Sindh" was a joint evaluation conducted by external evaluator with complete collaboration of project team. Organization's management proposed to use the approach of realistic or contextual evaluation (by Pawson and Tilly) so that study can be useful for other organizations or individuals those who want to work on alternative energies in context of Sindh. Use of alternative energies is really important to protect our climate and environment. Environmental degradation will be very burning issue for our next generations, we need to do something for environmental protection. Being a rational social animal, it is our responsibility to deliver our environment and nature to our future generations as these are delivered to us by our ancestors.

When you move into field for application of alternative energies, it is not simple task to perform. As shared in detailed above under the chapter of findings, that MRDS faced lots of challenges to implement a 
small project of eight biogas plants in only two villages. Let's use the contextual analysis model of Pawson and Tilly $(\mathrm{C}+\mathrm{M}=\mathrm{O})$, where, $\mathrm{C}$ represents context, $\mathrm{M}$ represents mechanism and $\mathrm{O}$ represents outcome. Context are the conditions of community in which project was being implemented, these may include income, social life, politics, religion, gender beliefs, infrastructure, technology and education. For this project context was rural communities living in forest, with low literacy rate, low income and depending on agriculture and livestock. Project theory or mechanism was provisions of environmental education to male members of community, training on use of biogas plants and construction of biogas plants to achieve the outcome (preservation of forest wood). In project mechanism implementation team was very clear and specific, but during first quarter of project it was felt that project will not be running in the context any more.

That was the important learning for MRDS project team, after that project implementation strategy was changed at some level. Instead of taking the male community members on lead, women of selected households were mobilized, trained and brought to lead. The ultimate use of biogas plants was to provide cooking fuel and cooking was the job of women, so biogas plants were more important to women of community as compare to men members.

Apart from that change, project team were still required one more magical step to boost the communities and a second change happened in mechanism (experiment of gas mantel). People needed light during night at their cooking place and they also need a new and surprising thing to enhance their curiosity. Now the biogas plants were being used for two purposes, to cook and to light in the kitchen during cooking.

After the changes in mechanism or project implementation approach MRDS successfully achieved the outcome of reduction in wood cutting from Miyani and Khabirani forests, we saved 68,400 to $115,200 \mathrm{~kg}$ of wood during project years with construction of twenty biogas plants in twenty households.

Thought the use of biogas plant is not new in Sindh, Pakistan, the first experiment on biogas plant was conducted by Panhwar in 1959. Instead of no any initiative is taken by media, universities or government to promote the use of biogas plants. Few NGOs have partially worked on it and implemented short term small projects. Construction and maintenance of biogas plants is an expert job, communities need extensive training and experience in this regard. As per project learning, it is recommend to build the capacity of women of communities and facilitate them to build their habit on use of biogas plants through continuous mobilization and support.

\section{Recommendations}

(1) Any organization working on alternative energies needs to be research oriented and must have room for learning.

(2) For any project on alternative energies and environment, women should be given lead because they are more nature friendly and caring as compare to men.

(3) In case of projects on biogas plants, women of communities should be trained intensively, biogas is a technical job it is necessary to orient the women of communities regarding all the technical aspects of biogas plants.

(4) For any project on alterative energies, innovations must be given importance in project design.

(5) Organization should not avoid from un-planned innovations, in any case, this is the better way to learn.

\section{Literature Review}

[1] Wellinger, A., Murphy, J. P., and Baxter, D. 2013. The Biogas Handbook, Science, Product and Application. Cambridge: Woodhead Publishing Limited.

[2] Seadi, T. A., Rutz, D., Prassl, H., Köttner, M., Finsterwalder, T., Volk, S., and Janssen, R. 2008. Biogas Handbook. Esbjerg: University of Southern Denmark.

[3] Hazra, S., Lewis, J., Das, I., and Singha, A. K. 2014. 
Adoption and Use of Improved Stoves and Biogas Plants in Rural India. Working Papers of South Asian Network for Development and Environmental Economics.

[4] Gulbrandsen, L. 2011. "Development Implications and Sustainability of Biogas Plants in Njombe District, Tanzania." Master thesis, The Norwegian University of Life Sciences.

[5] Given, L. M. 2008. The Sage Encyclopedia of Qualitative Research Methods. California: SAGE Publications, Inc. Print ISBN: 9781412941631, online ISBN: 9781412963909.
[6] Ritchie, J., and Lewis, J. 2003. A Guide for Social Science Students and Researchers. Wiltshire: The Cromwell Press Ltd. ISBN: 0-7619-7109-2.

[7] Mason, J. 2002. 2nd Edition Qualitative Researching. Wiltshire: The Cromwell Press Ltd, ISBN 0-7619-7428-8.

[8] Eherlich, R. 2013. Renewable Energy a First Course. Broken Sound Park Way USA. ISBN: 978-1-46659944-4.

[9] Yin, R. K. 2011. Qualitative Research from Start to Finish. New York: A Division of Guilford Publications, Inc. ISBN 978-1-60623-701-4. 
Annex 1. Application of experiment

First step:

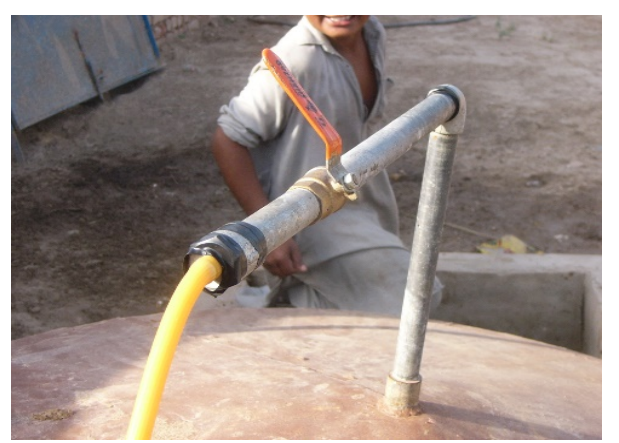

Attach gas nozzle at the top of pipe of biogas tank to increase the pressure of gas, it is nature of every gas its pressure increases as you press it. By making narrow path of gas we may increase the pressure of gas that is coming out of biogas tank. After attaching nozzle at the top of plant where from gas is coming, quantity of gas is same but its pressure is double.

Second step:

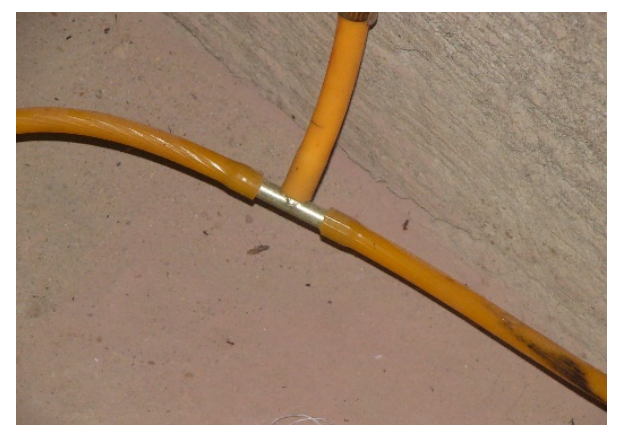

Attached a joint in gas line to make two connections one that moves to stove and other that moves to gas mantel. For making two connections you need a T-shape joint as seen in picture. Attach main line at one source, attach the line for stove with the opposite source and attach the line for mantel at the top of T- shape joint that line will move upwards where the mantel is hanged. Make sure that you have attached the line for stove right at the opposite of main line because you will require more pressure and amount of gas at stove for cooking.

Final step:

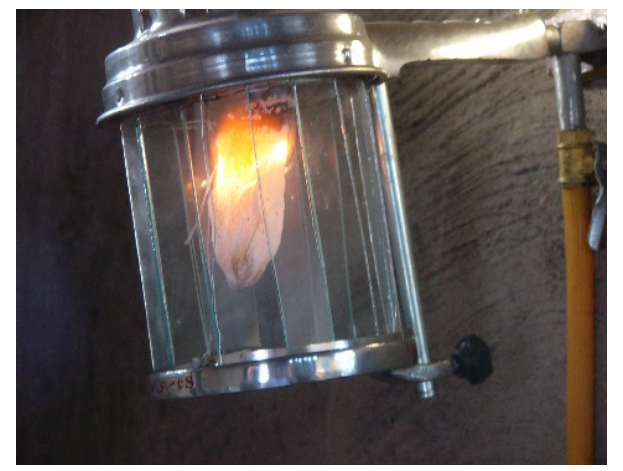

Attach a gas mantel at the end of one connection/gas line. Before attaching, please increase the size of nozzle of gas mantel by drilling with any strong pin so that coming gas can pass in excessive amount without any difficulty. One gas mantel can fully light the room of $16 \times 16$. Duration of lightening of gas mantel depends upon the size of biogas plant, amount of gas used for cooking $\&$ amount of green manure filled in biogas plant. 